\title{
Pengukuran Risiko Sistemik di Negara-negara Berkembang ASIA-7
}

\author{
Harun Arasyid ${ }^{1}$, Rinda Siaga $\mathbf{P}^{2^{*}}$ \\ ${ }^{1,2}$ Universitas Islam 45 \\ Jl Cut Meutia No.83 Bekasi, Jawa Barat \\ *correspondence email: rindasiaga@ymail.com
}

\begin{abstract}
The research on systemic risk is important to carry out in view of the alleged repetition of the eight-year crisis cycle affecting the market. The data of average stock returns calculation in almost all sample countries was negative in 2011 and repeated again in 2019 that the average banking stock returns in Malaysia, Thailand, the Philippines, Pakistan, and Sri Lanka showed a negative value. Even since 2018, the Philippines, Pakistan and Sri Lanka have consistently been shown to experience negative average returns. Systemic risk measurement is done by two methods, namely $\triangle$ CoVaR and MES. Furthermore, this research is very supportive and has been in line with the research roadmap of Islamic University 45 which states that in 2018 2026 the academic research is more focused on the application of regional technology and social engineering models that instead the products in the form of policies to then develop international standard research. In this study, the sample of countries used covers the Asian region, the topic discussed is a very important issue in the financial sector considering that systemic risk cannot be eliminated. In general, there are three findings that are explained from the results of the $\triangle$ CoVaR calculation that: (a) most developing countries experienced a decrease in their contribution to systemic events after the 2008 global crisis period; (b) large banks make the biggest contribution to systemic events, except for banks in Malaysia both small and large banks make equal contributions to systemic events; (c) There is a potential for systemic event to increase after 2019 that the contribution to systemic events by individual banks in the Philippines, Indonesia, Sri Lanka show an upward trend in the past year so that risk mitigation measures need to be taken in the form of policies and analysis of banking financial performance and global economic conditions. Based on the overall MES calculation the bank contributes more than $50 \%$ of potential systemic events to the system.
\end{abstract}

Keywords: Bank; Developing Countries; Systemic Risk.

\section{PENDAHULUAN}

Risiko sistemik merupakan risiko yang disebabkan oleh systemic events, termasuk financial institution failure hingga penutupan institusi keuangan oleh otoritas moneter, lebih lanjut, risiko sistemik tidak dapat dieliminasi bahkan mampu memberikan dampak negatif terhadap pasar keuangan maupun kondisi perekonomian global (Lo, 2008; Arena, 2008; Patro et. al. 2013). Pada saat lembaga keuangan mengalami failure secara bersamaan karena tidak kebal terhadap goncangan eksternal yang datang baik dari jatuhnya kondisi keuangan, perekonomian maupun sektor riil maka risiko sistemik tidak dapat dihindarkan (Lehar, 2005; Rodriges-Moreno et. al., 2010; Calmes \& Theoret, 2014). Selain itu, bank yang mengalami gagal bayar akan memunculkan efek domino dan sistemik yang dapat terjadi secara tiba-tiba akibat adanya gangguan sistem pembayaran hingga maturity mismatch, permasalahan pada arus kredit, bahkan dapat menyebabkan jatuhnya nilai aset (De Bandt dan Hartmann 2000; Group of Ten, 2001; Acharya, 2009; Vives, 2010; Patro et. al., 2013).

Terkait dengan risiko sistemik, terdapat konsep 4L (Leverage, Liquidity, Loss, dan Linkage) yang diperkenalkan oleh Billio et al. (2011) dan Bisias et. al. (2012) yang menyebutkan bahwa jika Bank mengejar return yang tinggi dengan meningkatkan leverage, banks' probability of loss juga akan meningkat. Jika bank mengalami kerugian, akan muncul masalah likuiditas yang berdampak pada sistem keuangan dan informasi atas kerugian bank dapat menyebabkan tindakan Bank runs oleh para deposan untuk menyelamatkan dana yang tersimpan di bank dan sudah tidak adanya kepercayaan terhadap bank (Chen, 1999; Allan \& Gale, 2004; Rose dan Hudgin, 2010). Selain itu, kondisi gagal bayar pada perbankan dapat memicu efek domino terhadap institusi keuangan lainnya dan hal ini akan meningkatkan potensi kejadian sistemik, sehingga pengukuran terhadap risiko sistemik ini sangat penting untuk dilakukan (Rochet \& Tirole, 1996; Bustaman, 2013).

Pengukuran risiko sistemik dapat dilakukan dengan beberapa metode, yakni: Top-Down, Bottom-Up, $\triangle$ CoVaR, Marginal Expected Shortfall (MES), SRISK, serta Clustering Coefficient dalam Network Analysis and Systemic Financial Linkages (Drehmanh dan Tarashev, 2011; Brownless dan Engle, 2012; Bisias et. al.,2012; Banulescu \& Dumitrescu, 2014; Tabak et.al., 2014). Top-Down merupakan pengukuran risiko sistemik yang dilakukan dengan asumsi bahwa distress pada perusahaan akan memapu memengaruhi distress sistem, sebaliknya Bottom-Up merupakan sebuah kondisi distress yang dialami oleh perusahaan-perusahaan akibat distress sistem secara makro (Popescu \& Turcu, 2014).

Secara konsep, pengukuran Top-Down dan Bottom-Up mirip dengan pengukuran MES dan $\triangle \mathrm{CoVaR}$. LopezEspinosa et. al., (2012), Lestari (2013), Yun \& Moon (2015), Pangestuti (2016), serta Zhao et.al. (2019) telah 
melakukan pengukuran risiko sistemik dengan menggunakan kedua metode tersebut dan menemukan bahwa $\Delta$ CoVaR sangat informatif dalam menangkap dinamika terkait risiko sistemik dalam sistem perbankan termasuk kontribusi marginal aset untuk menghitung return dari risiko sistemik dan eksekusi atas efek spillover dari satu aset terhadap aset lain dalam pasar, sementara MES dapat digunakan dalam operasi penjumlahan, selain itu, $\triangle \mathrm{CoVaR}$ dan MES mampu menjelaskan perbedaan cross sectional.

Penggunaan dua metode $\triangle \mathrm{CoVaR}$ dan MES lebih tepat digunakan dalam mengukur risiko sistemik karena saling melengkapi asumsi (bahwa kejadian sisteik dapat disebabkan dari dua sisi, yaitu dari pengaruh kondisi pasar yang distress atau adanya default pada bank) dan model pengukuran risiko sistemik yang sesuai dengan kondisi bank dapat digunakan sebagai Early Warning Signal (EWS) dalam mencegah terjadinya risiko sistemik pada industri perbankan (Bustaman, 2013; Yun dan Moon, 2014, Jonghe et. al., 2015; Lestari, 2015). Penggunaaan kedua metode ini mengingat metode lain seperti Clustering Coefficient dalam Network Analysis and Systemic Financial Linkages yang relatif sulit dilakukan karena memerlukan data pinjaman antar bank (Tabak et. al., 2014) dan SRISK yang menggunakan data book value of debt enam bulanan yang tidak berubah meski saat krisis (Banulescu \& Dumitrescu, 2014).

Pengukuran risiko sistemik yang tepat dapat membantu otoritas moneter dalam melakukan pemantauan terhadap stabilitas perbankan, utamanya perbankan di negara-negara berkembang yang berada dalam kawasan Benua Asia. Negara-negara berkembang dipilih karena sangat rentan terhadap krisis global juga krisis yang terjadi di negaranegara maju termasuk adanya guncangan krisis keuangan global dimulai dari krisis Meksiko pada 1994-1995, Asia Tenggara dan Asia Timur pada 1997-1999 (Indonesia, Korea, Malaysia, Filipina, dan Thailand), dan Brazil pada 1999, serta adanya macroeconomic shocks lain sehingga sehingga stabilitas keuangan pada negara berkembang menjadi hal yang menarik untuk diteliti (Nilsen \& Rovelli, 2001; Goldstein \& Xie, 2009; Hadian, 2012; Keffala, 2015).

Data jumlah negara berkembang dapat diakses melalui situs Asian Development Bank yang telah beroperasi di 40 negara di Benua Asia (ADB, 2019). Setidaknya ada tujuh negara berkembang di dalam ADB yang dapat diakses data harga saham secara lengkap selama 20 tahun terakhir (Datastream Thomson Reuters, 2019). Adapun ketujuh negara berkembang tersebut adalah Indonesia, Malaysia, Thailand, Filipina, India, Pakistan, serta Sri Lanka. Selain mempertimbangkan kelengkapan data, pemilihan ketujuh negara sampel tersebut juga dilakukan mengingat adanya fakta bahwa potensi risiko sistemik di negara-negara tersebut selama kurun waktu 1999-2019 mencerminkan sebuah siklus delapan tahunan terkait dengan adanya gejolak makro dan peningkatan risiko sistemik perbankan utamanya pada periode tahun 1999/2000 hingga 2001 dan 2008-2009. Potensi risiko sistemik dapat dilihat dari data rata-rata return saham perbankan di negara-negara berkembang Asia-7 yang berada pada nilai negatif pada periode tertentu selama 1999-2019 sebagai berikut:

\section{Grafik 1}

Rata-rata Return Saham Perbankan Asia-7 Periode 1999-2019

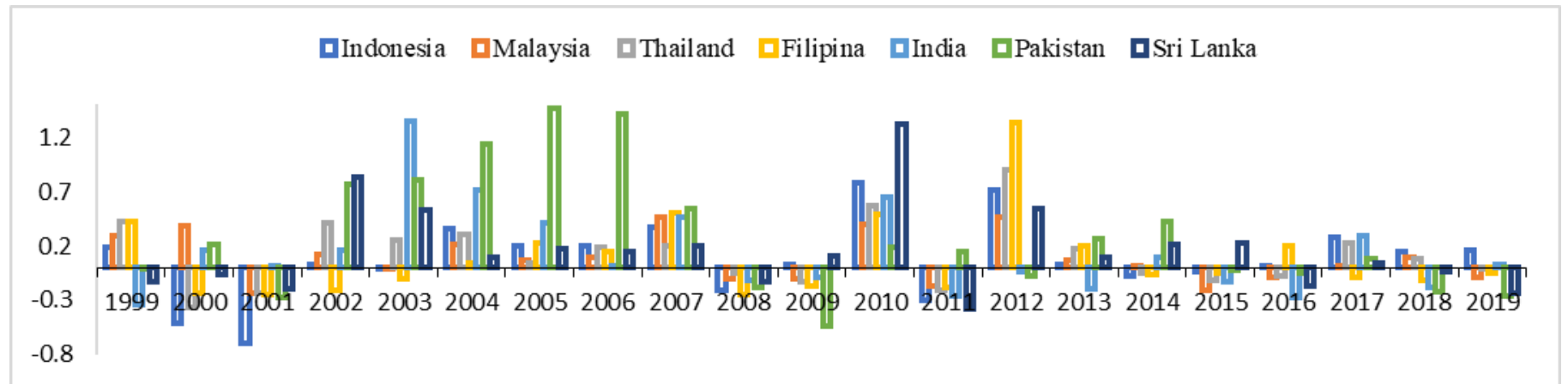

Sumber: Data diolah, 2019.

Berdasarkan data yang diambil dari Datastream Thompson Reuters yang disajikan dalam Grafik 1 diketahui bahwa rata-rata return saham pada perbankan di Asia-7 berada di posisi negatif di India, Pakistan, dan Sri Lanka pada 1999, disusul oleh Indonesia, Thailand, Filipina, serta Sri Lanka pada 2000, dan Indonesia, Thailand, Filipina, Sri Lanka, Malaysia, serta Pakistan pada 2001. Setelah delapan tahun kisaran periode krisis 1999-2001 terjadi, krisis kembali terjadi pada 2008 yang membuat return saham menjadi negatif di semua negara sampel selama tahun tersebut. Bahkan berdampak hingga tahun 2009 dan hanya Indonesia dan Sri lanka yang mampu memperbaiki kondisi harga saham hingga meraih return positif pada 2009. Pada grafik tersebut juga terlihat bahwa setelah periode krisis 2008-2009, return saham kembali negatif di semua negara sampel kecuali Sri Lanka pada 2015 juga Indonesia dan Filipina pada 2016. Terkait dengan hal ini, Jonghe et. al. (2015) telah menyebutkan bahwa krisis dapat memengaruhi 
peningkatan risiko sistemik, sementara perhitungan risiko sistemik sendiri dimulai dari harga saham pada perusahaan sampel selama periode penelitian.

Penelitian terkait risiko sistemik ini sangat penting untuk dilakukan mengingat adanya dugaan pengulangan siklus krisis delapan tahunan yang memengaruhi pasar dimulai dari kisaran tahun 2008-2009 dan terulang pada kisaran tahun 2015-2016. Hingga dugaan siklus return pasar yang negatif pada 2011 terulang setelah delapan tahun, yakni pada 2019 mengingat hasil perhitungan rata-rata return saham di hampir semua negara sampel adalah negatif pada 2011 dan kembali terulang pada 2019 yang mana Malaysia, Thailand, Filipina, Pakistan, serta Sri Lanka mengalami rata-rata return negatif pada 2019 bahkan sejak 2018, Filipina, Pakistan, dan Sri Lanka secara konsisten juga terbukti mengalami rata-rata return yang negatif. Dengan demikian, pada penelitian ini, periode sampel yang akan digunakan adalah tahun 2009-2019 mengingat adanya kondisi distress pasar pada 2015-2016, penurunan ratarata return saham di sebagian besar negara sampel pada 2011 dan berlanjut pada 2019, dan mengingat metode pengukuran risiko sistemik dengan MES dapat digunakan untuk memprediksi potensi risiko sistemik pada tahap moderat (Idier et. al., 2013; Wei $\beta$ et. al., 2014) atau sebelum siklus krisis delapan tahunan berikutnya yang berpotensi terjadi di tahun 2023-2024.

Lebih lanjut, penelitian ini telah sejalan dengan roadmap penelitian Universitas Islam 45 yang menyebutkan bahwa pada 2018-2026 penelitian akademik lebih berfokus pada penerapan lokalregional model teknologi dan rekayasa sosial yang malahirkan produk berupa kebijakan untuk kemudian dilakukan pengembangan penelitian berstandar internasional. Pada penelitian ini, sampel negara yang digunakan mencakup wilayah Asia, topik yang dibahas adalah masalah yang sangat penting di bidang keuangan mengingat risiko sistemik ini tidak dapat dieliminasi (Lo, 2008) dan yang memiliki efek contagion sehingga sulit untuk dipulihkan, penelitian terkait risiko sistemik pada negara-negara berkembang di Asia-7 belum pernah dilakukan karena memang kompilasi data yang diperlukan sulit untuk didapatkan secara lengkap dan berbayar, penggunaan referensi yang diambil dari publikasi artikel internasional yang umumnya berbayar untuk akses secara lengkap, serta saran berupa kebijakan yang dihasilkan dari analisis terhadap hasil olah data sehingga penelitian ini patut untuk dilaksanakan dan dipublikasikan khususnya sebagai bahan pertimbangan regulator perbankan di setiap negara dalam menentukan kebijakan terkait stabilitas keuangannya.

\section{METODE}

Pengukuran risiko sistemik dilakukan dengan menggunakan dua metode, yakni metode $\Delta$ CoVaR (Girardi dan Ergun, 2013) dan metode Marginal Expected Shortfall (MES) (Acharya, 2010). Adapun alasan penggunaan kedua metode tersebut karena arah pengukuran risiko sistemik yang dilihat dari dua sudut pandang. Pertama, risiko sistemik yang diakibatkan oleh individual Bank jika mengalami default pada kondisi perekonomian normal yang diukur dengan $\triangle \mathrm{CoVaR}$. Kedua, risiko sistemik yang diakibatkan oleh default Bank secara keseluruhan akibat adanya kondisi distress pasar yang diukur dengan MES.

Risiko sistemik individual bank menggunakan metode $\Delta \mathrm{CoVaR}$ mengikuti Girardi dan Ergun (2013) yang dimulai dari perhitungan nilai Value at Risk (VaR) masing-masing Bank $j$ menggunakan estimasi model univariate sebagai berikut:

$R_{t}^{j}=\mu_{t}^{j}+\varepsilon_{j, t}$

yaitu, $\mu_{t}^{j}=\alpha_{0}+\alpha_{1} R_{t-1}^{j} ; \quad \varepsilon_{j, t}=z_{j, t} \sigma_{j, t}$

dengan $z_{j, t}$ adalah i.i.d pada zero mean dan unit variance, sedangkan conditional variance dispesifikasi dengan GARCH $(1,1)$ pada persamaan:

$\sigma_{j, t}^{2}=\beta_{0}^{j}+\beta_{1}^{j} \varepsilon_{j, t-1}^{2}+\beta_{2}^{j} \sigma_{j, t-1}^{2}$

Selanjutnya, dilakukan estimasi model bivariate GARCH dari bank $j$ dan pasar dengan DCC Engle untuk setiap bank $j$, yakni $R_{t}=\left(R_{t}^{s}, R_{t}^{\prime}\right)$ yang mana nilai joint dynamic dihitung dengan persamaan:

$R_{t}=\mu_{t}+\varepsilon_{t}$

$\varepsilon_{t}=\Sigma_{t}^{1 / 2} z_{t}$

$\Sigma_{t}$ : matrik $(2 \times 2)$ conditional variance dari error term $\varepsilon_{t}$

$\mu_{t}:$ matrik $(2 \times 1)$ vector dari conditional meanz $z_{t}$ : i.i.d yakni $\Sigma_{t}^{-1 / 2}\left(R_{t}-\mu_{t}\right)$

$\mathrm{D}_{\mathrm{t}}$ adalah matrik diagonal $(2 \mathrm{x} 2)$ dengan conditional variance $\sigma_{x, t}^{2}$ dan $\sigma_{y}{ }^{2}, t$ pada posisi diagonal sehingga $\left[D_{x x}\right]_{t}=\left[\Sigma_{\mathrm{xx}}\right]_{t}$ , $\left[D_{y y}\right]_{t}=\left[\Sigma_{\mathrm{xx}}\right]_{t}$ dan $\left[D_{x y}\right]_{t}=0$ untuk $x, y=s, j$. Model GARCH $(1,1)$ digunakan untuk conditional variance dengan persamaan:

$\sigma_{x, t}^{2}=\theta_{0}^{x}+\theta_{1}^{x} \varepsilon_{x, t-1}^{2}+\theta_{2}^{x} \sigma_{x, t-1}^{2}$

$\sigma_{y, t}^{2}=\theta_{0}^{y}+\theta_{1}^{y} \varepsilon_{y, t-1}^{2}+\theta_{2}^{y} \sigma_{y, t-1}^{2}$ 
dengan nilai conditional variance $\sigma_{x, y}$ yang ditentukan dengan persamaan:

$\sigma_{x y, t}=\rho_{x y, t} \sqrt{\sigma_{x, t}^{2} \sigma_{y, t}^{2}}$

dengan asumsi $C_{t}=D_{t}^{-1 / 2} \Sigma_{t} D_{t}^{-1 / 2}=\left[\rho_{x y}\right]$ adalah matrik (2x2) dari conditional correlation $\mathrm{e}_{t}$. Engle (2002) menyebutkan bahwa matriks conditional correlation mengikuti persamaan:

$C_{t}=\operatorname{diag}\left(Q_{t}\right)^{-1 / 2} \times Q_{t} \times \operatorname{diag}\left(Q_{t}\right)^{-1 / 2}$,

$\underline{Q_{t}}=\left(1-\delta_{1}-\delta_{2}\right) \bar{Q}+\delta_{1}\left(u_{t-1} u_{t-1}^{\prime}\right)+\delta_{2} Q_{t-1}$

$\bar{Q}$ : matrik unconditional covariance dari $u_{t}=\left[\mathrm{e}_{x, t} / \sigma_{x, t}\right]_{x=s, j}$

$\operatorname{diag}(Q)_{t}$ : matrik $(2 \times 2)$ dengan posisi diagonal $Q_{t}$ dan zero off diagonal

Kemudian, dilakukan perhitungan untuk mendapatkan nilai $\operatorname{CoVaR}{ }^{s \mid j}{ }_{q, t}$ berdasarkan persamaan:

$\int_{-\infty}^{\mathrm{CoVaR}_{q, t}^{s \leq b j}} \int_{\mu_{t}^{j}-\sigma_{t}^{j}}^{\mu_{t}^{j}+\sigma_{t}^{j}} p d f_{t}(x, y) d y d x=p_{t}^{j} q$

Perhitungan risiko sistemik dilanjutkan dengan menggunakan metode MES yakni pada saat pasar mengalami distress mengikuti penelitian Acharya (2010). Acharya (2010) mendefinisikan MES bank sebagai perkiraan kerugian yang conditional pada saat default pasar lebih besar dari VaR pada $\alpha \%$ yang dalam hal ini adalah $5 \%$. MES bank $i$ diestimasi dengan menghitung rata-rata return saham bank pada saat conditional event yakni hari dimana pasar rugi secara ekstrim. Adapun model pengukuran MES menurut Acharya (2010) sebagai berikut:

$M E S_{i}^{5 \%}=-\mathrm{E}\left\{\frac{\mathrm{N}_{1}{ }^{\mathrm{i}}-1}{\mathrm{~W}_{0}{ }^{\mathrm{i}}} \mathrm{I}_{5 \%}\right\}$

$\frac{\mathrm{W}_{1}{ }^{\mathrm{i}}}{\mathrm{W}_{0}{ }^{\mathrm{i}}}$ : return saham bank

$\mathrm{I}_{5 \%}$ : Hari-hari pada saat pasar dengan $5 \%$ return terburuk.

Perhitungan jumlah hari dalam hal ini adalah sekitar 250 hari, dimana Bartram et. al. (2007) juga menggunakan estimasi sekitar 250 hari untuk mengukur hari-hari terburuk return pasar pada estimasi risiko sistemik. MES bank $i$ kemudian diestimasi dengan menghitung rata-rata return saham bank pada saat conditional event yakni hari dimana pasar rugi secara ekstrim. Adapun model pengukuran MES pada periode waktu $\left[T_{1} ; T_{2}\right]$ menurut Archarya (2010) sebagai berikut:

$M E S_{i}^{5} ;{ }_{[T 1 ; T 2]}=\frac{1}{\# \text { days in }\left[T_{1} ; T_{2}\right]} \sum_{t} ;$ system is in its $5 \%$ tail $R_{t}^{i}$

$R_{t}^{i}:$ return saham bank $i$ pada waktu $t$ dengan $t \in\left[T_{1} ; T_{2}\right]$

\section{HASIL}

Perhitungan risiko sistemik dilakukan sesuai tahapan-tahapan mengikuti Girardi dan Ergun (2013) yang dapat digunakan sebagai pengukur kontribusi perbankan secara individu terhadap risiko sistemik di negara-negara berkembang ASIA-7 dalam kurun waktu sepuluh tahun terakhir. Hal ini dilakukan untuk melihat tren kontribusi setiap bank terhadap sistem (kejadian sistemik) jika bank tersebut mengalami default. Adapun sampel yang digunakan adalah perbankan dengan aset yang relatif besar pada setiap negara berkembang tersebut mengingat adanya too-bigtoo-fail.

\section{Grafik 2}

Hasil Perhitungan $\Delta$ CoVaR di Filipina

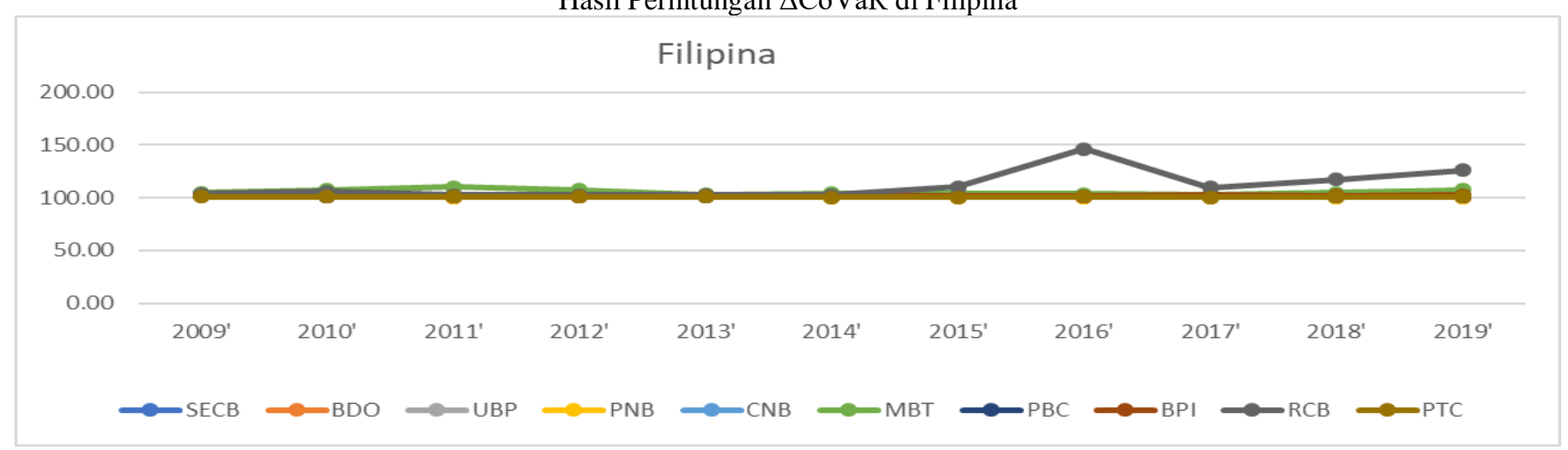

Sumber: Data diolah, 2019. 
Berikut adalah hasil perhitungan $\triangle \mathrm{CoVaR}$ untuk perbankan di Filipina. Terdapat 10 bank yang digunakan sebagai sampel dan terlihat bahwa pada tahun 2016 kontribusi risiko sistemik terbesar disumbangkan oleh RCB (Rizal Commercial Banking) hingga mencapai $146.27 \%$. Jika dilihat secara rata-rata bahwa semua perbankan di Filipina memberikan kontribusi hingga $100 \%$ terhadap kejadian sistemik. Artinya, jika salah satu saja dari bank tersebut mengalami default maka akan dapat memberikan kontribusi terhadap kejadian sistemik di negara tersebut. Jika dilihat dari tren, pada lima tahun pertama (2009-2014) kontribusi risiko sistemik di perbankan Filipina masih dalam rata-rata $100 \%$. Adanya peningkatan potensi sistemik akibat kontribusi individu bank jika terjadi default meningkat pada tahun (2015-2019). Hal ini dapat dijadikan sebagai antisipasi untuk melakukan tindakan mitigasi risiko dalam rangka meminimalisir adanya kejadian sistemik pada sistem perbankan di Filipina.

Grafik 3

Hasil Perhitungan $\Delta$ CoVaR di India

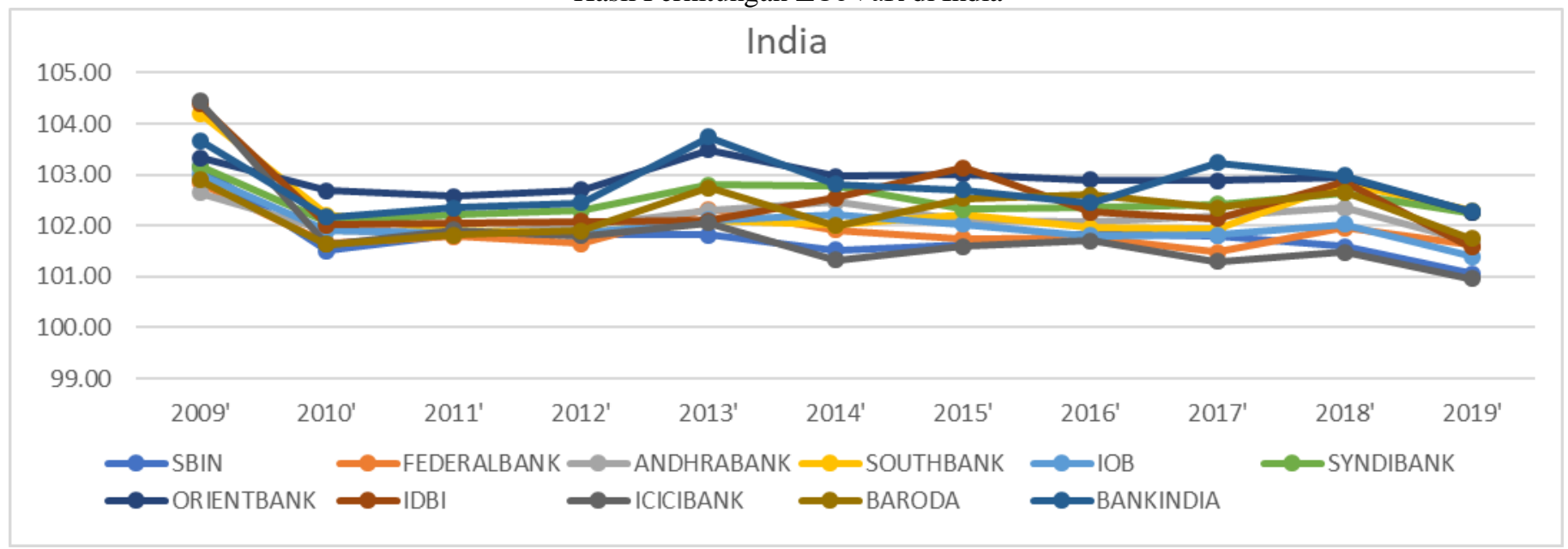

Sumber: Data diolah, 2019.

Berdasarkan grafik hasil perhitungan risiko sistemik terlihat bahwa semua perbankan di India mengalami penurunan kontribusi terhadap risiko sistemik dari tahun 2009 menuju tahun 2010. Hal ini mengingat adanya kondisi krisis global yang terjadi pada periode 2008 hingga 2009. Jika dilihat dari grafik, terlihat bahwa Bank of India memberikan kontribusi yang besar sepanjang periode pengamatan terhadap munculnya kejadian sistemik. Bank of India merupakan salah satu bank besar di negara tersebut, sehingga jika terjadi default maka kejadian sistemik tidak akan bisa dihindarkan. Jonghe et.al. (2015) juga menemukan hal serupa bahwa semakin besar bank semakin besar pengaruhnya terhadap risiko sistemik.

Grafik 4

Hasil Perhitungan $\Delta \mathrm{CoVaR}$ di Indonesia

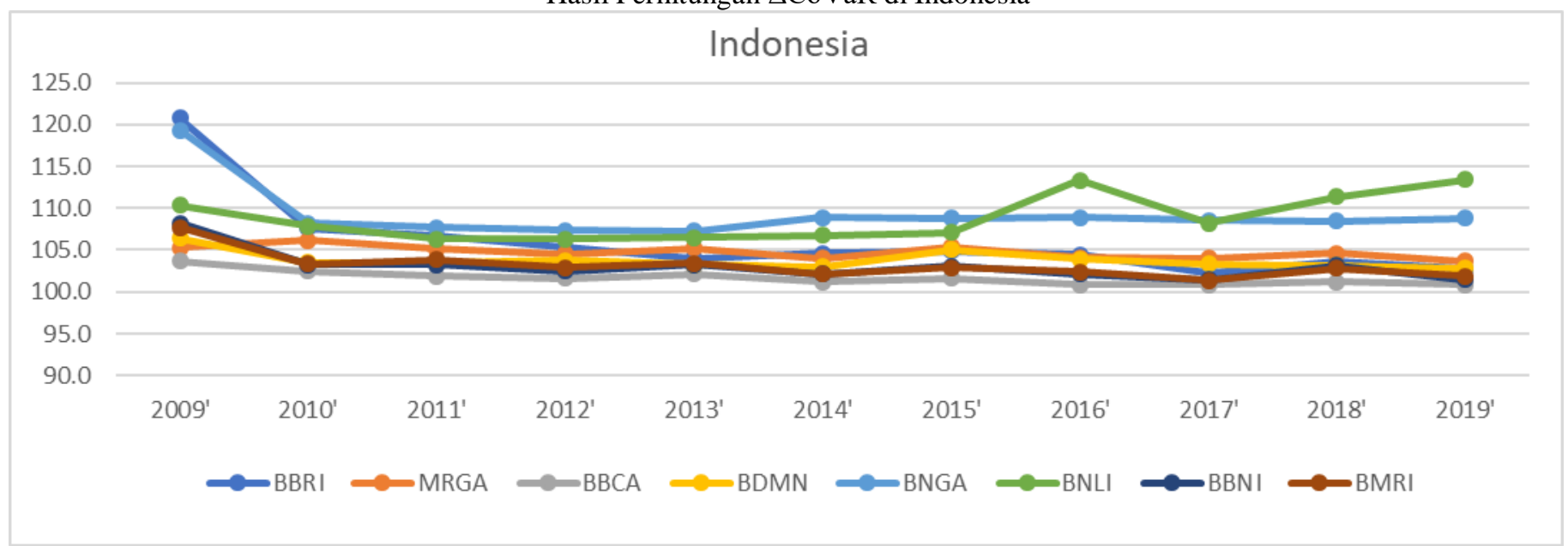

Sumber: Data diolah, 2019.

Kontribusi individu perbankan di Indonesia terhadap kejadian sistemik turun dari tahun 2009 menuju tahun 2010. Pola ini juga terbaca pada beberapa negara lain, yakni: India, Malaysia, Pakistan, Srilanka, serta Thailand. Artinya, bahwa krisis global yang terjadi pada periode 2008 hingga awal 2009 memberikan dampak terhadap 
pengambilan risiko bank dalam menjalankan bisnisnya. Meski rata-rata perbankan di Indonesia memberikan kontribusi terhadap risiko sistemik di atas 100\%, namun terlihat bahwa BNGA (Bank CIMB Niaga) dan BNLI (Bank Permata) memberikan kontribusi terhadap risiko sistemik yang lebih besar dibandingkan dengan perbankan lain. Kedua Bank ini bukanlah bank dengan aset terbesar di Indonesia namun kondisi ini kemungkinan bisa disebabkan oleh adanya jaringan antar bank terkaitan kegiatan pinjaman maupun pendanaan lainnya. Meski jika dilihat dari ratarata kontribusi risiko sistemik perbankan secara individu masing-masing bank berkontribusi hingga di atas 100\%.

Grafik 5

Hasil Perhitungan $\Delta \mathrm{CoVaR}$ di Malaysia

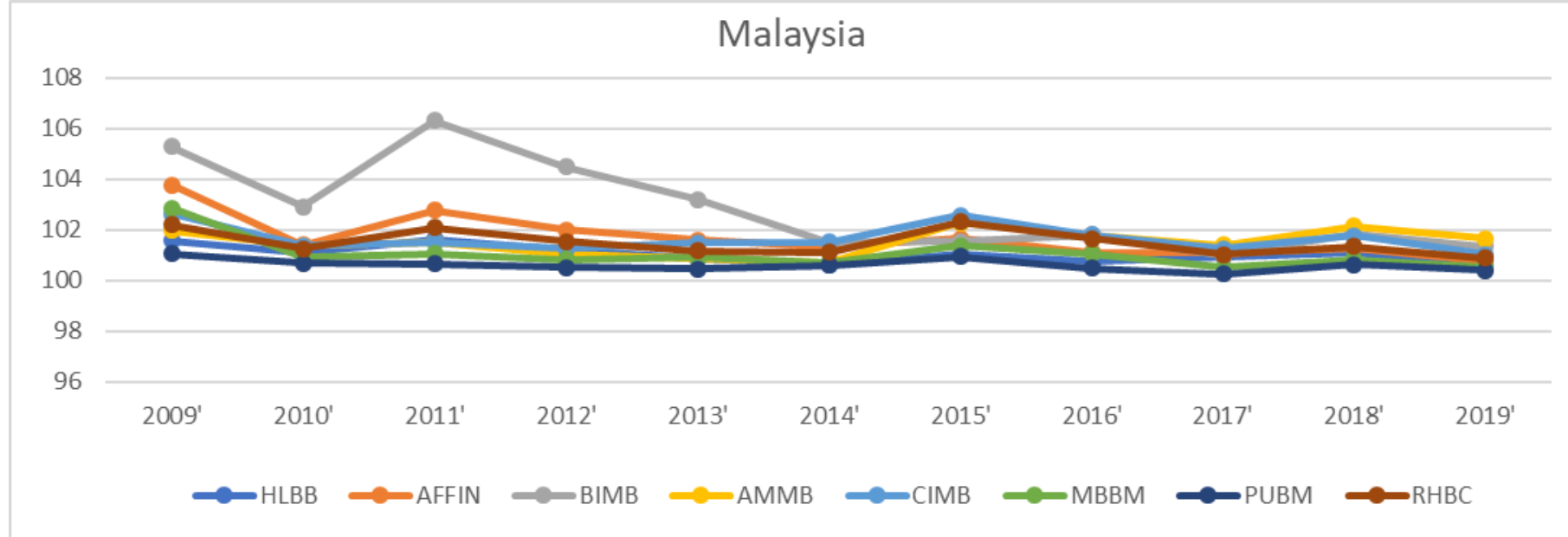

Sumber: Data diolah, 2019.

Pada penelitian terdahulu, Pangestuti (2018) menemukan bahwa ternyata karakteristik perbankan di Malaysia sedikit berbeda dengan perbankan di negara berkembang lainnya. Meski penelitian tersebut mengambil sampel periode tahun 2007-2013, hasil penelitian ini menunjukkan hal yang sama meski dalam periode waktu yang lebih baru. Terlihat dari Grafik 5 bahwa BIMB yang merupakan salah satu bank kecil di Malaysia memberikan kontribusi yang lebih besar terhadap kejadian sistemik. Zebua (2010) menyebutkan bahwa saat bank terindikasi default utmanya saat kondisi resesi ekonomi maka akan ada potensi Bank runs meski bank berukuran kecil. Dalam hal ini dapat dikatakan bahwa too-small-to-fail dapat terjadi pada perbankan di Malaysia meski bank-bank besar lainnya dalam kondisi solven. Rata-rata perbankan di Malaysia memberikan kontribusi terhadap kejadian sistemik hingga 100\% lebih.

Grafik 6

Hasil Perhitungan $\Delta$ CoVaR di Pakistan

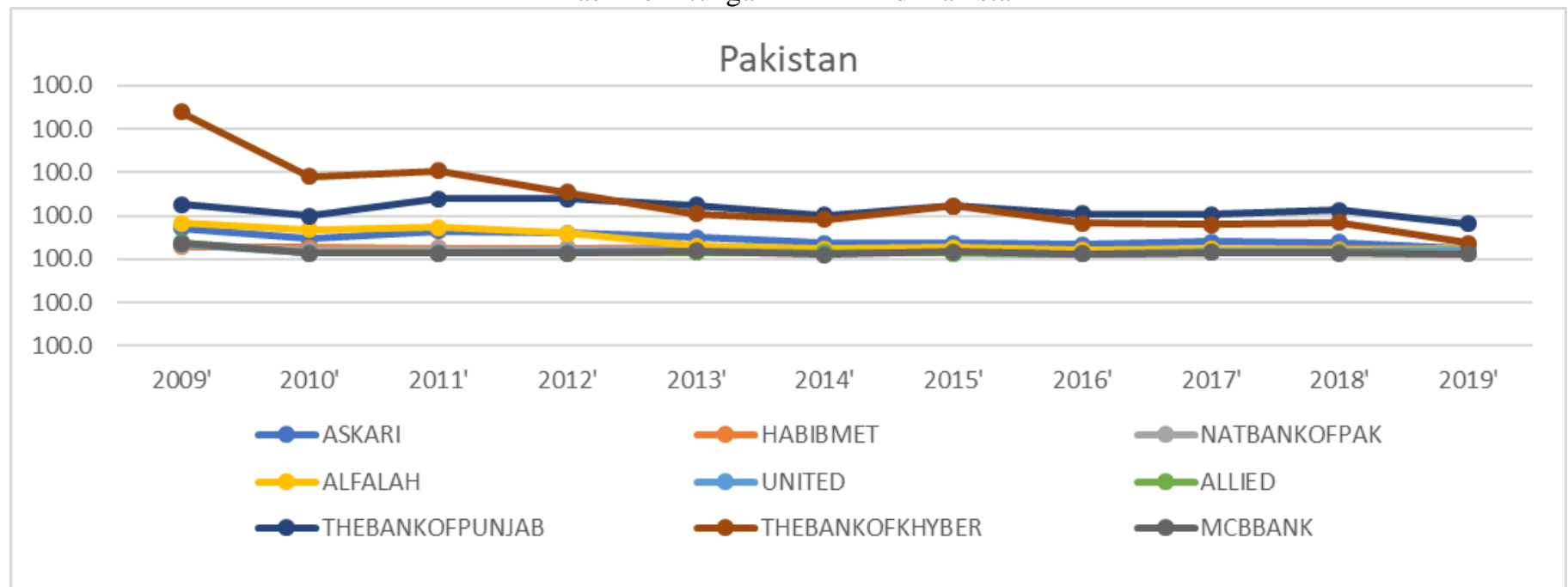

Sumber: Data diolah, 2019.

Tidak jauh berbeda dengan beberapa perbankan di negara berkembang lainnya, perbankan di pakistan memberikan kontribusi terhadap kejadian sistemik hingga 100\% lebih namun jika dilihat dari tren hasil perhitungan, 
kontribusi perbankan terhadap kejadian sistemik di Pakistan mengalami penurunan pada The Bank of Khyber. Perbankan lain relatif memberikan kontriusi yang tidak jauh berbeda selama 10 tahun terakhir.

Grafik 7

Hasil Perhitungan $\triangle \mathrm{CoVaR}$ di Srilanka

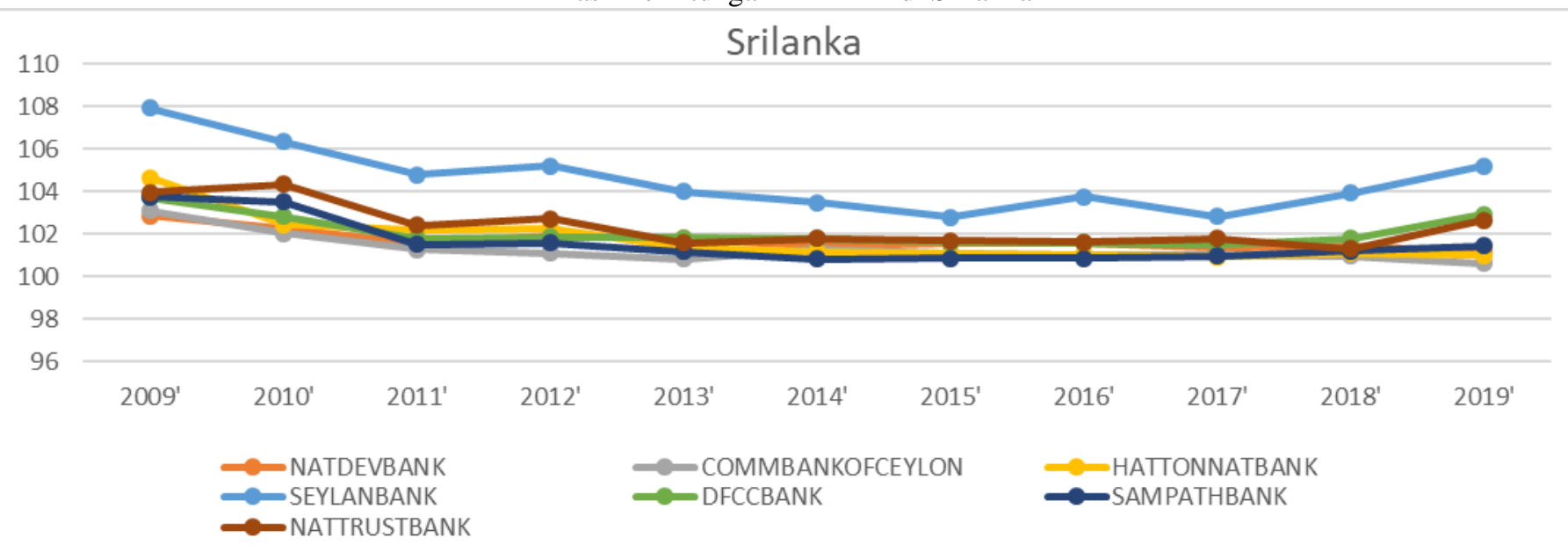

Sumber: Data diolah, 2019.

Berdasarkan grafik hasil perhitungan $\triangle \mathrm{CoVaR}$ terlihat bahwa Seylan Bank memberikan kontribusi terbesar dalam kejadian sistemik. Seylan Bank merupakan salah satu bank besar di Srilanka yang juga memberikan kontribusi atas kejadian sistemik yang terbesar juga. Ada hal yang perlu diperhatikan dari tren pada Seylan Bank ini bahwa selama kurun tahun 2009-2015 terjadi penurunan kontribusi terhadap kejadian sistemik, namun pada tahun 2016 hingga 2019 terjadi peningkatan tren sehingga perlu dilakukan antisipasi terhadap kondisi ini.

\section{Grafik 8}

Hasil Perhitungan $\Delta \mathrm{CoVaR}$ di Thailand

\section{Thailand}

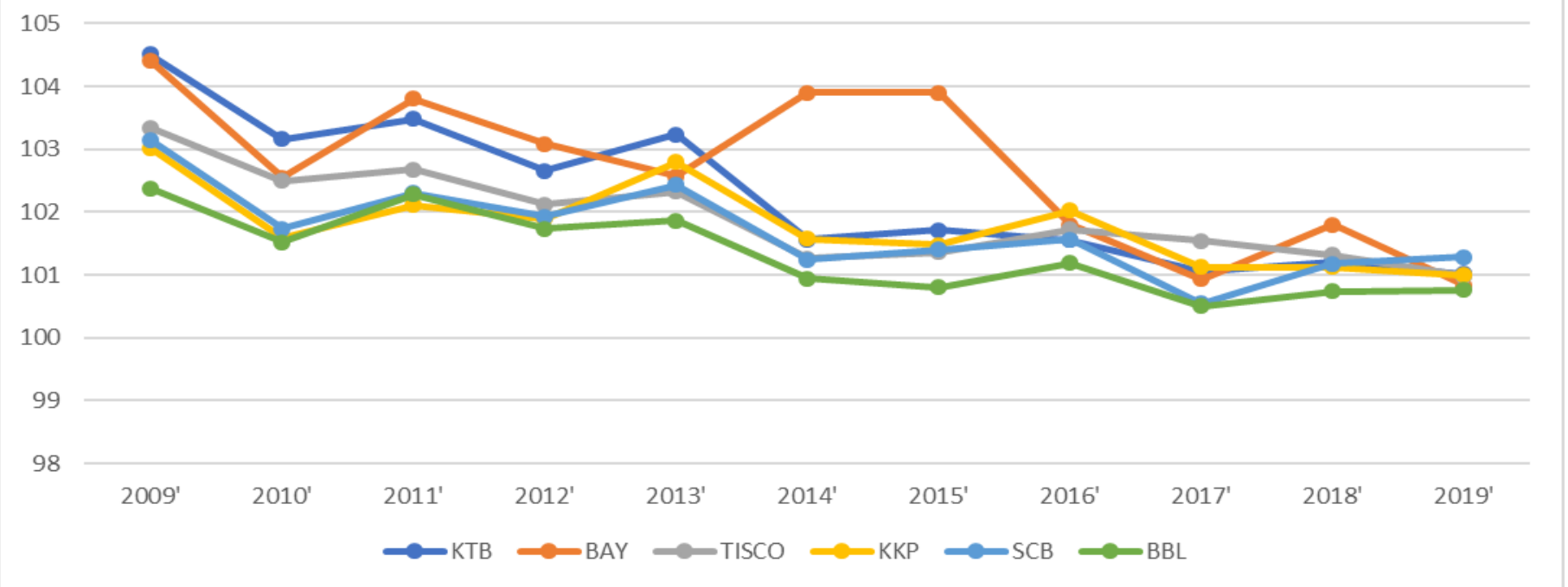

Sumber: Data diolah, 2019.

Thailand juga merupakan negara berkembang yang terkena dampak krisis global 2008 lalu. Terlihat dari grafik hasil perhitungan $\triangle \mathrm{CoVaR}$ bahwa terjadi tren penurunan kontribusi bank terhadap kejadian sistemik dalam 10 tahun terakhir. Adapun bank yang cenderung memberikan kontribusi yang tinggi terhadap kejadian sistemik adalah BAY (Bank of Ayudhya). Pangestuti (2018) menemukan bahwa pada saat kondisi krisis 2008, BAY mengalami peningakatan NPL (Non-Performing Loan) hingga 12\%. Idealnya, NPL adalah tidak lebih dari 5\%. Kondisi tersebut sangat berisiko karena terdapat kredit macet yang tinggi. 
Tabel 1

Hasil Perhitungan MES (Marginal Expected Shortfall)

\begin{tabular}{|c|c|c|c|c|c|c|c|c|c|c|c|}
\hline MES & 2009 & 2010 & 2011 & 2012 & 2013 & 2014 & 2015 & 2016 & 2017 & 2018 & 2019 \\
\hline Filipina & 46.5 & 63.6 & 47.3 & 90.0 & 108.0 & 57.9 & 70.3 & 86.7 & 32.7 & 90.6 & 57.3 \\
\hline India & 75.6 & 35.5 & 32.6 & 67.3 & 44.8 & 81.5 & 63.7 & 89.2 & 97.3 & 85.0 & 98.9 \\
\hline Indonesia & 39.2 & 73.3 & 98.3 & 94.0 & 87.5 & 63.5 & 48.6 & 30.3 & 85.5 & 51.6 & 42.5 \\
\hline Malaysia & 36.9 & 69.8 & 48.4 & 79.0 & 89.8 & 67.7 & 69.7 & 91.9 & 62.6 & 68.5 & 47.2 \\
\hline Pakistan & 42.7 & 69.6 & 46.9 & 122.5 & 108.3 & 63.6 & 51.1 & 60.5 & 74.8 & 85.1 & 106.1 \\
\hline Srilanka & 37.6 & 57.0 & 74.5 & 100.9 & 27.6 & 41.0 & 50.9 & 28.2 & 12.2 & 33.7 & 38.3 \\
\hline Thailand & 78.6 & 46.2 & 43.9 & 40.8 & 107.6 & 36.5 & 56.7 & 55.7 & 85.3 & 46.3 & 71.8 \\
\hline Average & 51.0 & 59.3 & 56.0 & 84.9 & 81.9 & 58.8 & 58.7 & 63.2 & 64.3 & 65.8 & 66.0 \\
\hline
\end{tabular}

Sumber: Data diolah, 2019.

Setelah dilakukan perhituangan $\triangle \mathrm{CoVaR}$ yang mengukur kontribusi individu bank terhadap kejadian sistemik jika bank mengalami default maka dilakukan perhitunagn MES yang mengukur kontribusi bank secara kumulatif terhadap kejadian sistemik pada saat pasar dalam kondisi distres akibat resesi perekonomian atau kondisi krisis (Yun \& Moon, 2014). Secara umum informasi dalam tabel hasil perhitungan MES adalah bahwa dalam kondisi distres pasar, perbankan di negara-negara nerkembang ASIA-7 memberikan kontribusi lebih dari 50\% terhadap kejadian sistemik selama periode sampel.

\section{SIMPULAN}

Secara umum terdapat tiga temuan yang dijelaskan dari hasil perhitungan $\Delta$ CoVaR bahwa: (a) sebagian besar negara berkembang mengalami penurunan kontribusi terhadap kejadian sistemik setelah periode krisis global tahun 2008; (b) Bank besar memberikan kontribusi yang paling besar terhadap kejadian sistemik, kecuali pada perbankan di Malaysia baik bank kecil maupun besar memberikan kontribusi yang sama besarnya terhadap kejadian sistemik; (c) Adanya potensi kejadian sistemik mengalami peningkatan setelah tahun 2019 ini mengingat kontribusi terhadap kejadian sistemik oleh individu bank di Filipina, Indonesia, Srilanka menunjukkan tren meningkat dalam satu tahun terakhir sehingga perlu dilakukan tindakan mitigasi dalam bentuk kebijakan dan analisis atas kinerja keuangan perbankan dan kondisi perekonomian global. Berdasarkan hasil perhitungan MES secara keseluruhan Bank memberikan kontribusi terhadap potensi kejadian sistemik lebih dari 50\% ke dalam sistem.

\section{DAFTAR PUSTAKA}

Acharya, Viral, V. (2009). A theory as systemic risk and design of prudential bank regulation. PhD Dissertaion of NYU.

Adrian, T., Brunnermeier, L. K.,. (2011). DCoVaR. NBER Working Paper No. 17454. 30.

Arena, Marco. (2008). Bank failures and bank fundamentals: A comparative analysis of Latin America and East Asia during the nineties using bank-level data. Journal of Banking \& Finance.

Bekhet, Ali H., Shorouq F. K. Eletter. (2014). Credit risk assessment model for Jordanian commercial banks: Neural Scoring Approach. Review of Development Science.

Berger, Allen N., Bouwman, Christa H. S. (2010). Bank liquidity creation, monitary policy, and financial crises. University of South Carolina, Wharton Financial Institutions Center, and CentER - Tilburg University.

Billio, M., Getmansky, M., Lo, Andres, dan Pellizon. (2010). Measuring systemic risk in the finance and insurance sector. MIT Sloan School, working paper \#4774-10.

Bisias et al. (2012). A survey of systemic risk analytics. Offfice of Financial Research, Working Paper \#0001.

Calmes, Christian, Theoret, R. (2014). Bank systemic risk and macroeconomic shocks: Canadian and US evidence. Journal of Banking and Finance, Vol 40, 388-402.

Chen, Yehning. (1999). Banking panics: The rule of the first-come, first-served rule and information externalities. Journal of Political Economy, 107, No.5.

Cubillas, E., Gonzales, F. (2014). Financial liberalization and bank risk-taking: International Evidence. Journal of Financial Stability, 11, 32-48. 32. Lestari, Nike. (2015). Kontribusi risiko sistemik dan hubungannya dengan karakteristik individual bank pada perbankan di Indonesia. Tesis. Universitas Indonesia.

De Bandt, O., Hartman, P., dan Peydro, J. L. (2010). Systemic risk in baking an update. Oxford Handbook of Banking, pp 634-664.

Freixas, X., Parigi, B. M., dan Rochet, J. C. (2000). Systemic risk, interbank relations, and liquidity proviosion by the central bank. Journal of Money, Credit and Banking, 32, 611-638.

Girardi, G., Ergun, A.T. (2013). Systemic risk measurement: Multivariate GARCH estimation of DCoVaR. Journal of Banking and Finance, 37, 3169-3180. 
Goldstein, Morris, Xie, Daniel. (2009). US crisis credit and spillovers to Asia. Peterson Institute for International Economics, 4, 204-222.

Group of Ten. (2001). Consolidation in the financial sector. Working Group Report, January.

Hadian. (2012). Analisis risiko sistemik pada sistem perbankan negara-negara ASEAN. Tesis Pasca Sarjana FEUI, Depok.

Idier, Julien, et. al. (2013). How useful is the Marginal Expected Shortfall for the measurement of systemic exposure? A practical assessment. Euro System, Working Paper Series, No. 1546.

Jackson, et. al. (2002). Regulatory and "Economic" solvency standards for internationally active banks. Journal of Banking \& Finance.

Jonghe, O.D., Diepstraten, M., Schepens, G. (2015). Bank's size, scope, and systemic risk: What the role for conflicts of interest. Journal of Banking and Finance.

Lehar, Alfred. (2005). Measuring systemic risk: A risk management approach. Journal of Banking \& Finance, 29, 2577-2603.

Lo, Andrew, W. (2008). Hedge funds, systemic risk, and the financial crisis of 20072008: Written twstimony for the House Oversight Committee Hearing on Hedge Funds. Social Science Researh Network.

Lopez-Espinosa, G., Rubia, A., Valderrama, L., Anton, M. (2013). Good for one, bad for all: Determinants of individual versus systemic risk. Journal of Financial Stability, 9, 287-299.

Nijskens, R., Wagner, W. (2011). Credit risk transfer activities and systemic risk: How banks became less risky individually but posed greater risks to the financial system at the same time. Journal of Banking and Finance, 35, 1391-1398.

Pangestuti, R.S. (2018). Pengaruh Risiko Sistemik terhadap Risiko Kredit dan Risiko Likuiditas pada Perbankan di ASEAN-4. Jurnal Ilmiah Akuntansi fakultas Ekonomi, Vol.4, No.1.

Patro, D.K., Qi, M., Sun, X. (2013). A simple indicator of systemic risk. Journal of Financial Stability, 9, 105-116.

Smaga, P. (2014). The concept of Systemic Risk. SRC Special Paper, August 2014.

Tabak, B. M., Takami, M., Rocha, J. M. Cajueiro, D. O., dan Souza, S. R, (2014). Directed clustering coefficient as a measure of systemic risk in complex banking networks. Physica A: Statistical Mechanics and its Applications, 394(0): 211-216.

Thornton, Henry. (1802). An Enquiry into the Nature and Effects of the Paper Creditof Great Britain. New York: Rinehart \& Company, Inc.

Uyemura, D. G., Van Deventer, Donald, R. (1993). Financial risk management in banking-the theory \& application of asset and liability management. Mc Graw Hill.

Vives, Xavier. (2010). Competition and Stability in banking. Working paper, IESE Business School.

Wei $\beta$, G.N.F., Bostandzic, D., Neumann, S. (2014). What factors drive systemic risk during international crises? Journal of Banking and Finance, 41, 78-96.

Yun, J., Moon, H. (2014). Measuring systemic risk in the Korean banking sector via dynamic conditional correlation models. Pasific-Basin Finance Journal, 27, 94-114.

Zebua A. (2010). Analisis Risiko Sistemik Perbankan di Indonesia. Program Pasca Sarjana. Institut Pertanian Bogor. 